\title{
Protein and Energy Utilization of Black Soldier Fly Maggot at Different age on Chicken
}

\author{
N. G. T. Marbun, M. Tafsin*, and Y. L. Henuk \\ Animal Production Program Study, Faculty of Agriculture, UniversitasSumatera Utara, Padang \\ Bulan, Medan 20155, Indonesia \\ *Correspondent author: martafsin@yahoo.com
}

\begin{abstract}
This study aims to determine the efficient use of protein and energy of Black Soldier fly larvae at different age levels on chicken. This research was conducted at Jl. RK, Desa Namo Bitang, Kecamatan Pancur Batu Kabupaten Deli Serdang, North Sumatra. Animal Husbandary Study Program, Faculty of Agriculture, Universitas Sumatra Utara, Medan. The design of this study was a completely randomized design (CRD) with 4 treatments and 5 replications. The treatment consisted of P0, P1, P2, and P3 (larvae 14, 21, 28 , and 35 days old). Observed variables were protein digestibility, nitrogen retention and apparent metabolizable energy.The results showedthat the treatment had a significant effect $(\mathrm{P}<0,01)$ on protein digestibility, nitrogen retention and apparent metabolizable energy. Based on research result it can be concluded that maggot of black soldier fly more efficient at the age between 24-25 days.
\end{abstract}

Keywords: black soldier fly maggot, protein digestibility, nitrogen retention, apparent metabolizable energy.

Received [4 July 2020] | Revised [24 July 2020] |Accepted [31 July 2020]

\section{Introduction}

Protein-based feed is feed that has the biggest share in the nutritional needs of livestock. Proteinbased feed are feed ingredients that have a protein content of at least $20 \%$. Protein-based feed can come from plants and animals. Protein-based feed derived from animals have advantages compared to those from plants, where the essential amino acid content is more complete.

To meet the needs of protein for livestock, the source of protein feedfrom animal commonly used is fish meal, because of its high protein content and easy to digest. The price of fish meal is high because Indonesia is still dependent on imported fish meal. Due to the high cost of fish meal, the price of feed increases, so that production costs increase, which in turn increases the selling price of livestock products [1].

Based on the above problems it is necessary to look for other alternative feed ingredients as a source of protein. One of them is protein-based feed from insects. The potential of insect as a protein-based feed is very promising, this makes the use of insect as a protein source has been widely discussed by researchers in the world such as [2] [3] and [4]. Insects are reported to have high feed conversion efficiency and can be maintained, and mass produced. 
As feed raw material, insect-based products must be safe from chemical contaminants [5] [6]. Maggot of Black soldier fly can be an option for supplying protein feed sources because this fly is easy to find, breed, and is one type of natural feed material that has high protein. Maggot is a black soldier fly (BSF) larvae or flower insect, has a texture that is chewy and has the ability to secrete natural enzymes. Maggot is one of the sources of high animal protein because it contains a range of 30-45\% protein and has been used as fish food and poultry. Maggot also has antimicrobial and antifungal properties, which can increase the body's resistance from bacterial and fungal diseases. This shows that BSF maggot is potentially used as an alternative feed.

BSF maggot life cycle starts from eggs, larvae, pre-pupae, pupae and then BSF flies. In the larval phase, pre-pupae and pupae can be used as feed ingredients [7] [8]. However, each phase has a different nutritional content and quality, so digestibility testing of maggot is needed [9]. Based on this the authors are interested in conducting research related to the efficient use of protein and energy of maggot black soldier fly at different age levels in chickens.

\section{Materials and Method}

This research was conducted at Jl. RK, Namo Bintang Village, Kec. Pancur BatuKab. Deli Serdang, North Sumatra. This research was conducted in August until October 2019. The equipment used was 20 units of modified metabolic cages with a size of $25 \mathrm{~cm} \times 25 \mathrm{~cm} \times 30 \mathrm{~cm}$, stool plastic storage, digital scales, 20 units of tumbler, lamps as lights, stationery and books. The materials used are adult male native chickens with a weight of $\pm 1-1.5 \mathrm{~kg}$ as many as 20 , rodalons, water, boric acid with a concentration of 5\%, fresh maggot flour at different ages: 14 days, 21 days, 28 days and 35 days.

\subsection{Method}

The study design used was a completely randomized design (CRD) consisting of 4 treatments and 5 replications. Each treatment consisted of 4 chickens asfollows:

P0: Maggot flour (larval phase / 14 days age)

P1: Maggot flour (larval phase / 21 days age)

P2: Maggot flour (pre-pupa phase / 28 days age)

P3: Maggot flour (pupa phase / 35 days age)

The changes observed in this study were as follows:

Protein digestion, nitrogen retention, apparent metabolic energy.

The data obtained were analyzed using analysis of variance. If the results of the variance analysis show differences, further tests will be conducted with theDuncan method. 


\section{Result and Discussion}

Table 1. Average digestibility values of BSF maggot protein

\begin{tabular}{ccccccc}
\hline \multirow{2}{*}{ Treatment } & \multicolumn{5}{c}{ Replications } & \multirow{2}{*}{ Average \pm SD } \\
\cline { 2 - 5 } & 1 & 2 & 3 & 4 & 5 & $72,67 \pm 1,11^{\text {a }}$ \\
\hline P0 & 72,56 & 73,42 & 70,97 & 73,86 & 72,55 & $68,46 \pm 0,96^{\text {b }}$ \\
P1 & 69,30 & 67,79 & 69,66 & 67,98 & 67,56 & $63,74 \pm 1,08^{\mathrm{c}}$ \\
P2 & 64,51 & 62,01 & 64,31 & 64,52 & 63,35 & $58,96 \pm 1,50^{\text {d }}$ \\
P3 & 58,16 & 56,94 & 60,23 & 60,60 & 58,86 & \\
\hline
\end{tabular}

Note: Different superscripts in the same row and column show very significant differences (P $<0.01)$.

Statistical test results showed that the use of BSF maggot flour had avery significant effect ( $\mathrm{P}<0.01$ ). The highest average value was $\mathrm{P} 0$ treatment at $72.67 \%$, then followed by $\mathrm{P} 1$ treatment at $68.46 \%$, then followed by P2 treatmentat $63,74 \%$ and the lowest in P3 treatment was $58.96 \%$. This study obtained the digestibility value of BSF maggot protein in the range of $58.96 \%$ $72.67 \%$. The range values indicate that the BSF maggot used in this study is low, medium and high quality. According to [9] statement that there are 3 categories of feed qualitybased on their digestibility, namely: digestibility values in the range of $50 \%-60 \%$ are low quality, between $60 \%-70 \%$ of medium quality and above $70 \%$ of high quality.

The results of this study indicate that the digestibility value of BSF maggot crude protein in P0 treatment has a higher value compared to P1, P2, and P3 treatments. The higher the age of BSF maggot, the higher the chitin content so that it can reduce digestibility. The high protein digestibility in the P0 treatment was due to the BSF maggot used in the P0 treatment was the younger BSF maggot among the other treatments.

The low digestibility of protein in the $\mathrm{P} 3$ treatment due to BSF maggot used in the P3 treatment is an older BSF maggot among other treatments. Based on the results of proximate analysis shows the crude protein content of BSF maggot in P0 treatment has a higher value among other treatments and P3 has a lower value among other treatments. This is in accordance with the statement.

[10] which states that in terms of age, larvae have a different percentage of nutritional components. Dry matter content of BSF larvae tends to be positively correlated with increasing age. The same thing also occurs in the components of crude fat, but in contrast to the crude protein component which tends to decrease in older age.

Decreased protein digestibility is also influenced by the presence ofchitin content in BSF maggot. Chitin is a polysaccharide compound found in the exoskeleton of an arthropod [11] which cannot be digested by most monogastricanimals including quail, due to the absence of the enzyme chitinase [12]. 


\subsection{Calculation of Nitrogen Retention}

Table 2. Mean BSF maggot nitrogen retention values

\begin{tabular}{ccccccc}
\hline \multirow{2}{*}{ Treatment } & \multicolumn{5}{c}{ Replications } & \multirow{2}{*}{ Average \pm SD } \\
\cline { 2 - 6 } & 1 & 2 & 3 & 4 & 5 & $72,04 \pm 1,58^{\mathrm{a}}$ \\
P0 & 71,88 & 73,12 & 69,62 & 73,73 & 71,86 & $66,23 \pm 0,37^{\mathrm{b}}$ \\
P1 & 67,43 & 65,28 & 67,96 & 65,55 & 64,94 & $59,41 \pm 1,55^{\mathrm{c}}$ \\
P2 & 60,52 & 56,93 & 60,23 & 60,52 & 58,85 & $52,40 \pm 2,14^{\mathrm{d}}$ \\
P3 & 51,26 & 49,53 & 54,22 & 54,74 & 52,25 & \\
\hline
\end{tabular}

Note: different superscripts in the same column show very significant differences $(\mathrm{P}<0.01)$.

Based on the results of diversity analysis (ANOVA) BSF maggot has a very significant effect ( $\mathrm{P}$ $<0.01)$ on nitrogen retention. The average retention value of BSF maggot nitrogen is around $52.40 \%-72.04 \%$. The nitrogen retention values from the highest to the lowest were obtained at $\mathrm{P} 0$ treatment at $72.04 \%, \mathrm{P} 1$ treatment at $66.23 \%, \mathrm{P} 2$ treatment at $59.41 \%$ and $\mathrm{P} 3$ at $52.40 \%$.

The results of this study indicate the nitrogen retention value of BSF maggot in the P0 treatment has a higher value compared to the treatments P1, P2, and P3. High and low nitrogen retention is influenced by differences in the level of protein content in the BSF maggot. [13] stated that nitrogen retention depends on the level of protein in the feed, the nitrogen content retained in line with the protein content of the feed. Nitrogen retention is influenced by several factors, namely: ration consumption, protein consumption and protein quality. The higher the consumption of rations, the higher nitrogen retention will be.

\subsection{Pseudo Metabolic Energy Calculation}

Table 3. Average pseudo metabolic energy values of BSF maggot

\begin{tabular}{ccccccc}
\hline \multirow{2}{*}{ Treatment } & \multicolumn{5}{c}{ Replications } & \multirow{2}{*}{ Average \pm SD } \\
\cline { 2 - 6 } & 1 & 2 & 3 & 4 & 5 & \\
\hline P0 & 3072,66 & 3011,09 & 2923,23 & $30,82,59$ & 2994,97 & $3016,91 \pm 64,64^{\mathrm{a}}$ \\
P1 & 3402,32 & 3524,13 & 3384,19 & 3325,34 & 3374,52 & $3402,10 \pm 73,93^{\mathrm{c}}$ \\
P2 & 3569,41 & 3471,47 & 3421,09 & 3542,79 & 3505,72 & $3502,10 \pm 58,52^{\mathrm{b}}$ \\
P3 & 3569,41 & 3471,47 & 3421,09 & 3542,79 & 3505,72 & $3597,69 \pm 35,85^{\text {d }}$ \\
\hline
\end{tabular}

Note: different superscripts in the same column show very significant differences $(\mathrm{P}<0.01)$.

Statistical test results showed that the use of BSF maggot flour had avery significant effect ( $\mathrm{P}<0.01)$. The average pseudo metabolic energy value of BSF maggot is around 3016.91 $3597.69 \mathrm{kcal} / \mathrm{kg}$. Pseudo metabolic energy values from highest to lowest were obtained in the treatment P3 of $3597.69 \mathrm{kcal} / \mathrm{kg}$ P2 treatment of $3502.10 \mathrm{kcal} / \mathrm{kg}, \mathrm{P} 1$ treatment of $3402.10 \mathrm{kcal}$ / kg and P0 of $3016.91 \mathrm{kcal} / \mathrm{kg}$.

The results of this study indicate the pseudo metabolic energy value of BSF maggot in P3 treatment has a higher value compared to $\mathrm{P} 0, \mathrm{P} 1$, and $\mathrm{P} 2$ treatments. The high apparent pseudo metabolic energy value in $\mathrm{P} 3$ treatment is due to the high gross energy content in BSF maggot P3 treatment. The high energy consumption gives an illustration that high energy metabolic rate. This 
is in accordance with the opinion of [14], which states that the higher the energy consumption, the higher the metabolic energy.

The low pseudo metabolic energy value in the P0 treatment is due to the low gross energy content in the P0 treatment. Factors affecting metabolic energy according to [15] digestibility of metabolic energy is influenced by the gross energy of feed and the amount of energy used by livestock.

\section{Conclusion}

The increasing age of maggot in line with the increase of chitin contentin maggot and vice versa if the age of maggot gets younger then the chitin content in maggot will be lower. Chitin content in maggot can reduce digestibility. Based on a review of energy and protein utilization among the 4 treatments, it shows that the age of BSF maggot is more efficient at the age between 24-25 days.

\section{REFERENCES}

[1] Suwarsito dan Cahyo P. Pemanfaatan Limbah Ampas Tahu Sebagai Pakan Ikan Sebagai Budidaya Ikan Nilem Didesa Cikembulan Kecamatan Pekucen Kabupaten Bayumas. Laporan Penelitian.Universitas Muhammadiyah Purwokerto; Purwokerto. 2005.

[2] D. Josefiak and R.M. Engberg. Insects as Poultry Feed. 20th European Symposium on Poultry Nutrition. Prague. Czech Republic. 2015.

[3] M.Khosro, A. Nicholas, N.K. Andrew. Insects as Poultry Feeds: A scoping study for poultry production systems in Australia. World's Poultry Science Journal, Vol 68. 20012.

[4] S.H.Khan. Reviews:Recent advances in role of insects as alternative protein source in poultry nutrition. Journal of Applied Animal Research Vol 46, 2018-Issue 1.

[5] N Moula, J Detileux. A meta-analysis of teh effects of insects in feed on poultrygrowth performances. Animal (Basel) 2019 May 9 (5) 201.

[6] M. Shumo, Isaac M.Osuga, F.M.Khamis, C M. Tanga, Komi K, M Fiiabee, S Subramanian, S Ekesi, A van Huis, C. Borgemeister. The nutritive value of black soldier fly larvae reared on common organic waste streams in Kenya. Scientific Reports 9 Article Number: 10110 (2019).

[7] S Diener, Z. Zurbrugg, K. Tockner. Convertion of organic material by black soldier fly larvae: establishing optimal feeding rates. Waste Management \& Research -July 2019. DOI: 10.1177/0734242X09103838.

[8] M.S.Muhayyat, A.T. Yuliansyah, A. Prasetya. Pengaruh Jenis Limbah dan umpan pada biokonversi limbah domestik menggunakan larva Black Soldier Fly (Hermetia Illucens). Jurnal Rekayasa Proses Volume 10 No. 1, 2016.

[9] Charlton AJ, Dickinson M, Wakefield ME, Fitches E, Kenis M, Han R, Zhu F, Kone N, Grant M, Devic E, et al. 2015. Exploring the chemical safety of fly larvae as a source of protein for animal feed. J Insects Food Feed. 1:7-16. 
[10] Wardhana, A. H. Black soldier fly (Hermetia illucens) sebagai sumber protein alternatif untuk pakan ternak. Wartazoa : Buletin Ilmu Peternakan Dan Kesehatan Hewan Indonesia, 26(2), 69-78.2016 https://doi.org/10.14334/wartazoa.v26i2.1327Henry M, Gasco L, Piccolo G, Fountoulaki E. Review on the use of insectsin the diet of farmed fsh: Past and future. Anim Feed Sci Technol. 203:1-22.doi: 10.1016/j.anifeedsci.2015.03.001.2015.

[11] Sánchez-Muros MJ, Barroso FG, Manzano-Agugliaro F. Insect meal asrenewable source of food for animal feeding: A review. J. Clean. Prod. 65:16-27. doi: 10.1016/j.jclepro.2013.11.068.2013

[12] Mc Donald, P. R. A., Edwards and J. F.H. Greenhalgh.

[13] Animal nutrition. Fourth edition. Longman. Hongkong. 1977

[14] Storey, M. L.and N. K. Allen. Apparent and True Metabolizable Energy of Feedingstuffs for Manure, Non-Laying Female Ambden Geese. Poultry Sci. 60: 739-747.1982

[15] Saputra, P. H., O. Sjofjan dan I. H. Djunaidi. Pengaruh penambahan fitobiotik meniran(Phyllanthus niruri,L.) dalam pakan terhadap kecernaan protein kasar dan energi metabolis ayam pedaging.Universitas Brawijaya. Malang.2001 